\title{
MEDICINAL PLANTS OF SELECTED WETLANDS IN ARIYANNUR, THRISSUR DISTRICT,
} KERALA-A PRELIMINARY STUDY

\author{
K. R. ATHIRA \\ Guest Lecturer, Department of Botany, Sreekrishna College, Guruvayur, Thrissur, Kerala, India \\ Email: athirakramachandran37@gmail.com
}

Received: 12 May 2019, Revised and Accepted: 15 Jul 2019

\section{ABSTRACT}

Objective: Wetlands are a vital ecosystem which provides livelihoods for millions of people who live within around them. The main aim of this study is to identify the wetland medicinal plants, medicinal values of wetland medicinal plants, to evaluate the current status of the medicinal plant diversity in wetlands of Ariyannoor area, importance of wetlands, to build awareness.

Methods: Frequent field visits were carried out from September 2018 to January 2019 to collect different Wetland medicinal plants in Ariyannur area, Kandanassery Panchayath, Thrissur district. Plants were collected carefully with hand and identified by using the standard literature such as Flora of the Presidency of Madras by J. S. Gamble, 1915-1936. The collected plants were authenticated by a plant Taxonomist Dr. Udayan. P. S. A total of 10 plant species was collected and identified during the investigation with potential medicinal value.

Results: These plants are used for curing more than 20 diseases, including Blood dysentery, cough and cold, skin diseases, anemia etc. Herbs have been called part of "nature's pharmacy". Although their action can in some ways be similar to modern drugs, herbal remedies are generally gentler and safer. Many of the drugs used in conventional medicine are derived from herbs [1].

Conclusion: Slight alteration of the wetland may result in the disappearance or the extinction of these plants ${ }^{2}$. This will ultimately result in large scale economic loss in terms of the medicinal product. Apart from the loss of plants, this will also result in the loss of local knowledge on the medicinal properties of these plants which very often can't be retrieved. An attempt has been made to document some of the little known medicinal properties of wetland plants used by local community.

Keywords: Wetland, Ecosystem, Herbalism, Medicinal plants, Extinction, Wetland plants, Pharmaceutical industry

(C) 2019 The Authors. Published by Innovare Academic Sciences Pvt Ltd. This is an open-access article under the CC BY license (http://creativecommons.org/licenses/by/4.0/) DOI: http://dx.doi.org/10.22159/ijcpr.2019v11i5.35699

\section{INTRODUCTION}

India has a rich wealth of important medicinal flora and its varied climate is ideally suited for the cultivation of medicinal plants. Quality of plant-derived medicine is a matter of great concerns as the utilization of plant materials for cure of infections and chronic human diseases is increasing [2]. One of the oldest repositories of human knowledge, the Rig-Veda (4500-4600BC) mentioned the use of medicinal plants for the treatment of one or other disease [3]. Ethnomedicinal uses of 48 wetland plant species of South Orissa and discussed their conservation [4]. The present work reviews the utilities of wetland plant species as medicine with the help of authentic publications and by the incorporation of traditional knowledge of local communities in this aspect. Wetlands cover approximately $5 \%-8 \%$ of the global land area [5]. A wetland is a land area that is saturated with water, either permanently or seasonally, such that it takes on the characteristics of a distinct ecosystem. Ramsar Convention defines wetlands as "areas of marsh, fen, peat land or water, whether natural or artificial, permanent or temporary, with water that is static or flowing, fresh, brackish or salt, including areas of marine water the depth of which at low tide does not exceed six metres". Wetlands provide a unique habitat for several medicinal plants [6]. In spite of their commercial value, the local community utilizes good number of these plants for various curative purposes. A number of these plants are very sensitive to the fluctuation in the normal physic-chemical parameter of the wetland. A slight alteration of the wetland may result in the disappearance or the extinction of these plants [1]. This will ultimately result in large scale economic loss in terms of the medicinal product. Apart from the loss of plants, this will also result in the loss of local knowledge on the medicinal properties of these plants which very often can't be retrieved. The attempt has been made to document some of the little known medicinal properties of wetland plants used by local community. There are many different types of wetlands. These include areas of marsh, fen, peat land and shallow water bodies. Most are natural but some are human made, and they can be permanent or seasonal. Despite this definition, modified from the Ramsar Convention on Wetlands (1971), there are different interpretations of what constitutes a wetland around the world. Measurement and mapping techniques also vary between countries and regions [7].

\section{MATERIALS AND METHODS}

Frequent field visits were carried out from September 2018 to January 2019 to collect different Wetland medicinal plants in Ariyannur area, Kandanassery pnachayath, Thrissur district. Plants were collected carefully with hand and identified by using the standard literature such as Flora of the Presidency of Madras by J. S. Gamble, 1915-1936. The collected plants were authenticated by a plant Taxonomist Dr. Udayan. P. S. from the Post Graduate and Research Department of Botany, Sree Krishna College, Guruvayur. The collected specimen was dried properly and preserved in the herbarium sheet.

\section{RESULTS}

Table 1: List of medicinal plants

\begin{tabular}{lllll}
\hline S. No. & Name and famaly & Lockel name & Parts used & Uses \\
\hline 1. & $\begin{array}{l}\text { Marsilea quadrifolia Linn } \\
\text { Marsileaceae }\end{array}$ & Water clover & Whole plant & It is helpful in treating cough leprosy and dyspepsia \\
\hline
\end{tabular}


Athira

\begin{tabular}{|c|c|c|c|c|}
\hline 2. & $\begin{array}{l}\text { Mimosa pudica L. } \\
\text { Mimosaceae }\end{array}$ & Shameplant & $\begin{array}{l}\text { Roots and leaves } \\
\text { dyspepsia }\end{array}$ & $\begin{array}{l}\text { couh, plant is used internally for vesicle calculi and externally } \\
\text { for rheumatism }\end{array}$ \\
\hline 3. & $\begin{array}{l}\text { Mollugo pentaphylla L. } \\
\text { Aizoaceae }\end{array}$ & $\begin{array}{l}\text { Five leaved } \\
\text { carpetweed }\end{array}$ & Whole plant & The plant is used as a laxative Medicine and emmenagogue. \\
\hline 4. & Oryza sativa L. Poaceae & Rice & Roots and grains & They are useful in vitiated conditions of pitta, pneumonosis \\
\hline 5. & $\begin{array}{l}\text { Phyllanthus airy-shawii Brunel } \\
\text { and Roux. euphorbiaceae }\end{array}$ & Keerharnelli & Whole plant & It is used to cure blood infections \\
\hline 6. & $\begin{array}{l}\text { Scoparia dulcis } \mathrm{L} . \\
\text { Scorphuleriaceae }\end{array}$ & Sweet broom & Whole plant & A decoction is used in the treatment of fever and gonorrhea \\
\hline 7. & Senna tora (L.) Roxb. Fabaceae & Sickle senna & Whole plant & Leaves and stem are used for diabetes. \\
\hline 8. & Sida acuta Burm. f. Malvaceae & $\begin{array}{l}\text { Common } \\
\text { wireweed }\end{array}$ & Whole plant & $\begin{array}{l}\text { The juice of the plant is used for indigestion and is good for } \\
\text { body aches }\end{array}$ \\
\hline 9. & $\begin{array}{l}\text { Smithia conferta Smith. } \\
\text { Malvaceae }\end{array}$ & Lakshman booti & Leaves and roots & $\begin{array}{l}\text { It is used in the treatment of biliousness, } \\
\text { ulcers, rheumatism etc. }\end{array}$ \\
\hline 10. & $\begin{array}{l}\text { Solanum torvum Sw. } \\
\text { Solanaceae }\end{array}$ & Turkey berry & Whole plant & $\begin{array}{l}\text { The leaves are applied for cuts, wounds and } \\
\text { Skin diseases }\end{array}$ \\
\hline
\end{tabular}

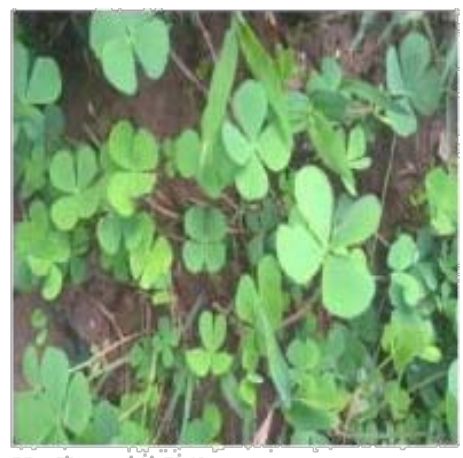

Marsilia quadritoliáninn:

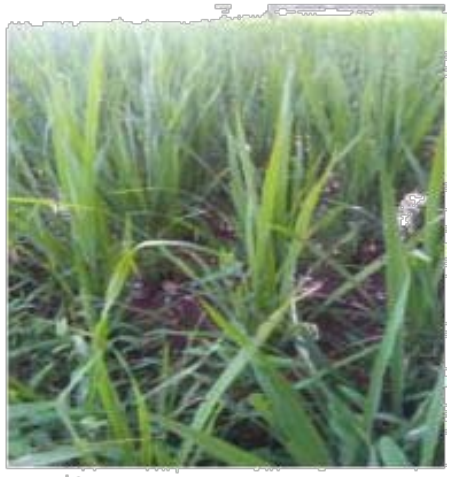

Oryio viativa $\mathrm{L}$.

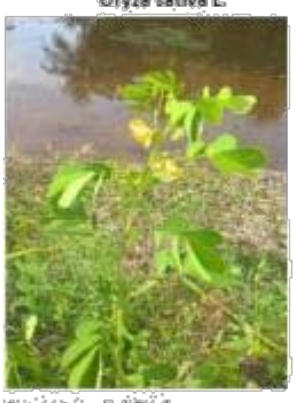

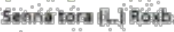

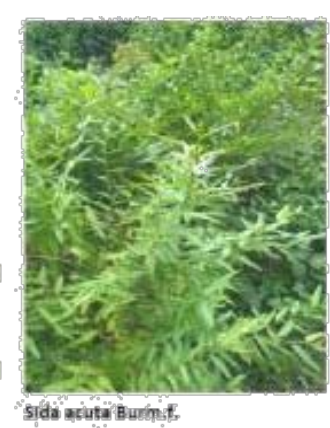

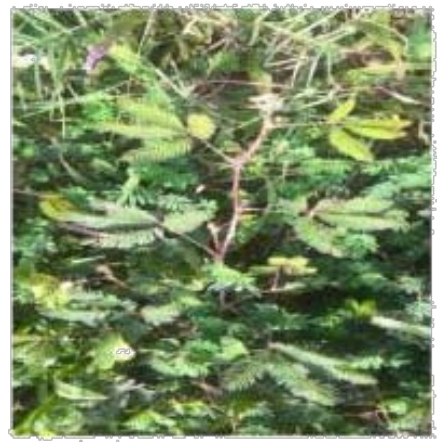

Mimiosa pudical

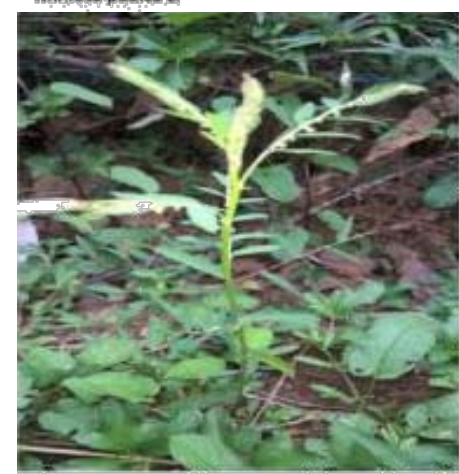

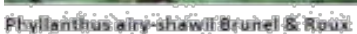

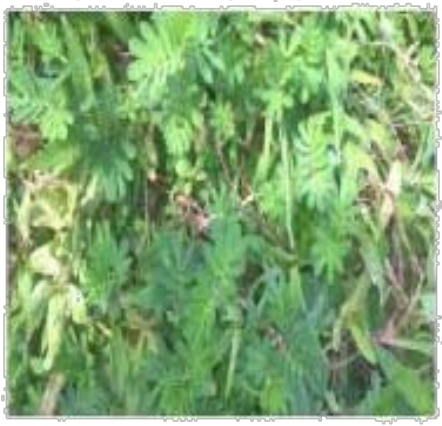

Smithla conferata smith

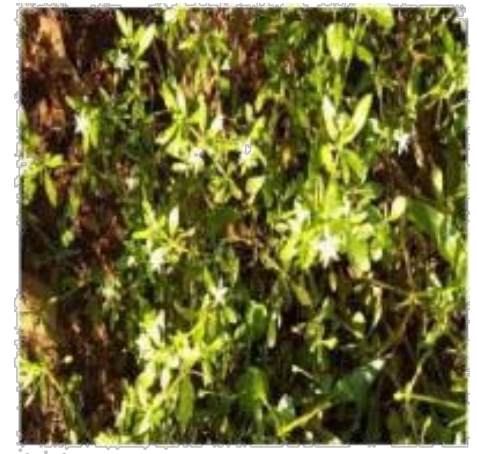

Molliago pertaphylla L

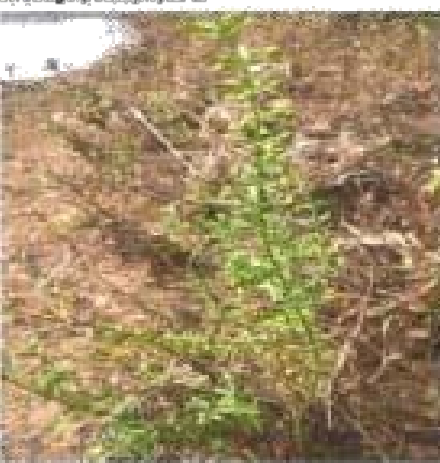

scisparia duftcist?

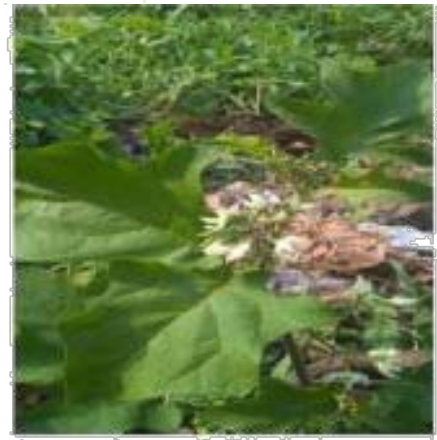

Solanum torvium sw

Fig. 1: Common wetland medicinal plants seen in Ariyanoor area

\section{DISCUSSION}

The present study showed that family Fabaceae occupy the first position followed by Poaceae and Solanaceae. In the study area the flora showed 16 Herbs (64\%); 9 Shrubs (36\%). Alternanthera bettzickiana and Mimosa pudica are the invasive plants found in the study area. These weeds arethe indication of the disturbance in the vegetation of the area. Hygrophyllaschulli, Mimosa pudica,
Ludwigia hyssopifolia, Colocassia esculenta, Oryza sativa, Desmodium trifolium and Cyperus tenuispica are the dominatingspecies. The identified plants belonged to different families and maximum number of plants were found to be coming under the family Fabaceae, Solanaceae and Poaceae. Out of 17500 flowering plant species known from India, more than 4000 species are used as medicinal plants [4]. Over exploitation and indiscriminate use of wild resources in commercial demand acting 
as the major factors in disturbing the entire ecosystem. Destruction of wetlands is mainly due to the intrusion of nonnative species, draining wetlands for agricultural purposes and mosquito control, dikes and dams to form ponds and lakes, pollution from landfills, water pollution, pesticide usage, removal of vegetation, land pollution, air pollution etc [5]. wetlands are providing a key link in watershed management, protects water quality, controls flooding, serves as home for many plants and animals, and providing various types of medicinal plants. There are various efforts to conserve wetlands. They are various nature conservancy proposes mainly rehabilitation, construction of new wetlands, minimize damage to wetlands, Conservation of wetland flora and fauna 4 . While considering the importance of ethno botanical studies it should be remembered that many times the natives do not like to share their knowledge with others. Also, for majority of the diseases it so happens that not a single plant is administered but is given in combination with many plant parts, all of which again may not be encountered in a particular field trip [6]. Sometimes, the same plant is suggested for more than one disease. In such cases it is very difficult to assess which plant is actually effective in curing a particular disease [7]. Only clinical trials on these plants can give some indications. The wetlands affect water quality through nutrient cycling, sediment deposition, ion and molecular absorption and temperature modification [8]

\section{CONCLUSION}

The present study is a preliminary step for the identification of valuable medicinal plants in the wetlands of Ariyannur area. This attempt was made since it is equally important to understand the traditional medicines and beliefs as well as to have scientific awareness for protection and conservation of these wetlands. Increased demand for plant derived drugs is putting pressure on high value medicinal plants and risking their biodiversity. From this minor study 25 species of wetland plants belonging to 19 families were recorded to be used by the traditional medicine practitioners. Increasing populations, urbanization and deforestation are contributing to species endangerment in developing countries. The decrease or elimination of medicinal plants is increasing due to the over exploitation and unsustainable development. These medicinal plant remedies comparatively have certain advantages, as these are easily accessible and affordable to rural community. The wetlands have a vast wealth of plants, which are sources of medicinal compounds. On the other hand loss of important floral diversity also leads to declining of it. Hence conservation of floral diversity will be important tool to sustain and carry such important knowledge to the future generation. The flora is the most important factor to maintain the biodiversity of an area.

\section{ACKNOWLEDGEMENT}

First of all I would like to show my deep sense of gratitude to the Almighty God whose unbounded ray of blessings enriched my thoughts and deeds and also gave good health, strength and self confidence. I feel extremely honored for the opportunities given to me to work under the supervision of Dr. Udayan. P. S. Head of the Department of Botany, Sreekrishna College Guruvayur, Thrissur, for the continuous and valuable guidance and unstained encouragement through the course of these theses. My special thanks to the concerned authority of librarians of Sreekrishna College Guruvayur, Kerala Forest Research Institute (KFRI) Peechi, Kerala Agricultural University Central Library, Mannuthy, for my literature collection.

\section{AUTHORS CONTRIBUTIONS}

All the author have contributed equally

\section{CONFLICT OF INTERESTS}

Declare none

\section{REFERENCES}

1. Santosh K, Satya N. Herbal remedies of wetlands macrophytes in India. Int J Pharma Bio Sci 2010;1:12-6.

2. Sharma A, Shanker C, Tyagi LK, Singh M, Rao CV. Herbal medicine for market potential in India: an overview. Acad J Plant Sci Expandjournal 2008;1:26-36.

3. Yousaf Z, Wang Y, Baydoun E. Phytochemistry and pharmacological studies on Solanum torvum Swartz. J Appl Pharm Sci 2013;3:152-60.

4. Umdale SD, Kshirsagar PR, Lekhak MM, Gaikwad NB. Molecular authentication of the traditional medicinal plant "Lakshman Booti" (Smithia conferta Sm.) and its adulterants through DNA barcoding. Pharmacogn Magazine 2017;13(Suppl 2):S224.

5. Sarmah BP, Baruah D, Bakalial B. Wetland medicinal plants in floodplains of subansiri and ranga river of lakhimpur district Assam, India. Asian J Plant Sci Res 2013;3:54-60.

6. Abraham J, Thomas TD. Antibacterial activity of medicinal plant Cyclea peltata (Lam.) hook. f. and thoms. Asian Pacific J Trop Disease 2012;2:S280-S284.

7. Singh S, Nishteswar K. Review on Cissampelos pareira and Cycleapeltata patha dwaya) phyto-pharmacological perspectives. Int J Ayurvedic Med 2013;4:282-9.

8. Agrawal AD, Bajpei PS, Patil AA, Bavaskar SR. Solanumtorvum Sw.-a phytopharmacological review. Der Pharm Lett 2010;2:403-7. 